\title{
Studi Histologi Paru-Paru Kambing Peranakan Etawah
}

\author{
(HISTOLOGICAL STUDY OF ETAWAH CROSSBRED LUNG)
}

\author{
I Gede Semarabawa ${ }^{1 *}$, Ni Ketut Suwiti ${ }^{2}$ \\ ${ }^{1}$ Bidang Kesehatan Hewan dan Kesehatan Masyarakat Veteriner, Dinas Pertanian dan \\ Ketahanan Pangan Provinsi Bali. Jl. Raya WR Supratman No. 71 Denpasar, Bali; \\ ${ }^{2}$ Laboratorium Histologi Fakultas Kedokteran Hewan Universitas Udayana, Jl. PB Sudirman \\ Denpasar, Bali.*Email: semarabawaigede@gmail.com
}

\begin{abstract}
Abstrak
Penelitian ini bertujuan untuk mengetahui struktur histologi paru-paru kambing peranakan etawah. Enam puluh empat sampel berupa paru-paru, dari kambing peranakan etawah jantan dan betina yang berumur muda dan dewasa, dan dibuat sediaan histologi, diwarnai dengan metoda Harris-Hematoksilin Eosin. Hasil penelitian menunjukan struktur histologi paru-paru kambing peranakan etawah didominasi oleh alveoli, ditemukan bronkus dan bronkiolus dalam suatu kapsula. Tidak ada perbedaan ketebalan kapsula paru-paru kambing peranakan etawah jantan dan betina baik pada umur muda maupun dewasa $(\mathrm{P}>0,05)$, namun pleura visceral kambing betina muda lebih padat dibandingkan betina dewasa. Contour bronkus kambing peranakan etawah jantan lebih besar $(\mathrm{P}<0,05)$ dibandingkan betina baik pada umur muda maupun dewasa. Paru-paru kambing PE jantan memiliki tulang rawan hialin yang lebih banyak dibandingkan betina dengan bentuk pipih dan memanjang diluar adventitia, sedangkan pada betina berbentuk bulat. Contour bronkiolus kambing peranakan etawah jantan dewasa lebih besar $(\mathrm{P}<0,05)$ dibandingkan betina, sedangkan pada kambing muda bronkiolus betina lebih besar. Otot polos bronkiolus kambing jantan berbentuk lingkaran dengan batas yang jelas, sedangkan pada betina batasnya kurang jelas dan terputus-putus.
\end{abstract}

Kata kunci: kambing peranakan etawah; paru-paru; histologi; histomorfometri

\begin{abstract}
The aim of this research is to know about the histological structure and morphometry of lungs from the etawah crossbreed. This research used 64 samples taken from both young and adult Etawah crossbred goats and then made histology preparations. The histology preparations are colored by the Harris-Hematoxylin Eosin method. The results showed that the histological structure of the lungs of etawah crossbred goats was mostly composed of the alveoli, wrapped by the capsule, and in it was found bronchial and bronchioles. There are no differences in lung capsule thickness within male and female etawah crossbred goats for both young and adult ages $(\mathrm{P}>0.05)$, but the visceral pleura in female goats is denser than in adults. The bronchus contours of the male goats were larger $(\mathrm{P}<0.05)$ than females at both young and adult goats. Etawah crossbred male goat's lungs have more hyaline cartilage than females with flat forms where on the male it is elongated beyond adventitia whereas in female is round. Bronchioles contours in adult goats is larger $(\mathrm{P}<0.05)$ than in the female. On the other side, the bronchioles contour in young female goats is larger. The smooth muscles of males' bronchioles are circular with clear boundaries, while on females, its boundaries are not clear and discontinuous.
\end{abstract}

Keywords: goat etawah crossbred; lungs; histological structure; histomorphometry

\section{PENDAHULUAN}

Indonesia adalah negara agraris karena sekitar $85 \%$ penduduknya tinggal di pedesaan dan berprofesi sebagai petani. Pertanian mencakup berbagai sektor seperti perikanan, peternakan, perkebunan, dan kehutanan. Selain sektor perkebunan saat ini pengembangan sektor peternakan banyak digemari oleh masyarakat di Indonesia, dimana bertujuan untuk meningkatkan produksi ternak sehingga kebutuhan akan protein hewani berupa daging dan susu dapat terpenuhi. Salah satu 
jenis ternak yang banyak dikembangkan untuk menghasilkan daging di Indonesia adalah ternak kambing.

Ternak kambing merupakan salah satu jenis ternak yang memiliki prospek pengembangan yang baik dalam menyuplai kebutuhan daging (Suparman et al., 2016). Kambing merupakan ternak yang banyak dipelihara karena memiliki sifat yang menguntungkan, seperti dapat beradaptasi dengan baik terhadap lingkungan ekstrim dan efisien dalam mengkonversi pakan menjadi susu (Irmawati et al., 2013). Jenis kambing yang banyak dipelihara oleh masyarakat adalah kambing kacang dan kambing peranakan etawah (PE) (Prabowo, 2010).

Aspek kesehatan merupakan hal yang sangat perlu diperhatikan dalam pemeliharaan ternak kambing (Dhewiyanty et al., 2015). Salah satu organ yang menjadi indikator kesehatan kambing adalah paru - paru, apabila paru-paru terpapar oleh agen penyakit maka akan menimbulkan penyakit yang dapat mengganggu fungsinya. Terganggunya fungsi paru-paru dapat mengganggu sistem respirasi dalam tubuh. Paru-paru dapat berfungsi normal apabila dalam keadaan sehat dan tidak terinfeksi suatu agen kimia maupun agen biologi (Eroschenco, 2008), yang dapat diamati dengan pemeriksaan histologi.

Sistem respirasi terdiri dari paru-paru dan banyak saluran udara atau tabung dengan berbagai ukuran yang mengarah ke dan dari masing-masing paru (Eroschenko, 2008). Struktur paru- paru mirip dengan glandula alveolar komplek, terletak dalam cavum toracis dan bentuknya berubah-ubah sesuai dengan irama respirasi. Paru-paru terdiri dari rangka penyokong berupa kapsula dan jaringan ikat interstitial, bagian konduksi dalam paru-paru dan bagian respirasi (Eroschenko, 2008).

Paru- paru terbagi atas lobus, sedangkan lobus terbagi lagi menjadi lobulus oleh jaringan ikat tipis yang disebut septa. Lobulus berbentuk piramida, piramida-piramida tersebut tersusun sedemikian rupa sehingga bagian apex mengarah kehilus paru-paru, sedang bagian basisnya mengarah ke permukaan paruparu. Tiap lobulus menerima cabang dari bronkus primarius (merupakan cabang dari trakea) sedangkan lobulus menerima bronkiolus kecil.

Trakea bercabang menjadi dua di luar paru-paru disebut bronkus primaries atau ekstrapulmoner (Eroschenko, 2008). Tiap bronkus primarius bercabang-cabang sesuai dengan jumlah lobi. Bronkus masuk ke dalam paru - paru melalui hilus, cabangcabang bronkus primarius yang masuk kedalam lobulus disebut bronkiolus. Dibandingkan dengan bronkus maka bronkiolus memiliki epitel lebih kecil dan sudah tidak pseudokomplek melainkan kolumner bersilia, sudah tidak mempunyai kartilago. Bronkiolus akan bercabangcabang terus membentuk cabang lebih kecil. Cabang terkecil yang masih termasuk dalam bagian konduksi disebut bronkiolus terminalis. Bronkiolus terminalis melanjutkan diri sebagai 1-2 atau lebih bronkiolus respiratorius, ini bercabang lagi menjadi 2-11 duktus alveolaris yang dindingnya dibatasi oleh bangunan berupa rumah labah yaitu mulut lebar, saccus alveolaris yang merupakan bagian terujung. Bronkiolus terminal dilapisi oleh epitel kolumnar simplek (Eroschenko, 2008).

Struktur histologi bronkus intrapulmoner mirip dengan trakea dan bronkus ekstrapulmonal, kecuali pada bronki intrapulmoner, cincin kartilago berbentuk c dari trakea digantikan oleh lempeng kartilago yang bentuknya tidak teratur secara sempurna membatasi bronki (Eroschenko, 2008). Disamping itu ditemukan juga lapisan otot polos yang sempurna, lempeng-lempeng kartilago menghilang setelah diameternya mencapai $1 \mathrm{~mm}$. Bronkus ditutup oleh epitel pseudokomplek basilia, lamina proprianya dibentuk oleh banyak serabut elastis dengan sedikit serabut kolagen dan 
retikuler. Sejumlah limfosit ditemukan baik di dalam lamina propria dan di antara sel epitel (Mescher, 2016). Pada pemotongan melintang bronkus permukaannya kelihatan bergelombang karena kontraksi otot polos yang terdapat pada dinding. Gambaran ini akan hilang apabila paru-paru teregang.

Dari penjelasan di atas dapat diketahui betapa pentingnya peran paru-paru sebagai organ pernapasan. Oleh karena itu, perlu dilakukan penelitian struktur histologi dan histomorfometri pada paru-paru kambing peranakan etawah sebagai salah satu indikator kesehatan, disamping itu sampai saat ini belum ada penelitian sejenis yang dilakukan.

\section{METODE PENELITIAN}

\section{Sampel}

Sampel yang digunakan dalam penelitian ini sebanyak 64 paru-paru kambing peranakan etawah yang diambil dari tempat Pemotongan Hewan Kampung Jawa Denpasar. Sampel dibedakan atas umur dewasa (12-36 bulan) dan muda (512 bulan) (Edey, 1993; SNI 7352, 2015). Bahan-bahan yang digunakan pada penelitian ini adalah alkohol absolute, paraffin, xylol, kanada balsam, zat warna Hematoxillin-Eosin, aquades, formalin $10 \%$, alkohol 70\%, alkohol $90 \%$, dan toluene. Peralatan yang digunakan dalam penelitian ini adalah tissue prosesor, embedding set, mikrotom, penangas air, gelas obyek, scapel, gunting, pinset, pot-pot kecil, inkubator dan mikroskop. Jenis penelitian yang dilakukan menggunakan metode kualitatif dan kuantitatif. Rancangan penelitian menggunakan rancangan acak lengkap pola faktorial dengan dua faktor, umur (muda dan dewasa) dan jenis kelamin (jantan dan betina) (Federer, 1997).

\section{Pembuatan Sediaan Histologi}

Sediaan histologi dibuat dengan mengikuti metode Suwiti et al. (2015), dengan cara : sampel di dehidrasi dengan aquades, dan di clearing dengan satu sesi larutan Formalin 10\% I, formalin 10\% II, formalin $10 \%$ III, alkohol $70 \%$, alkohol 96\%, alkohol absolut I, alkohol absolut II, alkohol absolut III, xylol I, xylol II, xylol III, toluene I, toluene II, toluene III, paraffin cair selama \pm 23 jam, selanjutnya dibloking dengan alat embedding set yang sudah dituangi paraffin dan didinginkan selama \pm 30 menit di dalam lemari es. Sampel yang sudah di embedding lalu dipotong dengan ukuran \pm 3-4 mikron, selanjutnya diletakkan pada objek gelas.

\section{Pewarnaan Harris-Hematoksilin Eosin}

Pewarnaan dilakukan dengan cara, sediaan direndam dalam xylol I, II, III masing - masing selama 5 menit, direndam kembali dalam alkohol absolut I dan II masing - masing selama 5 menit. Setelah itu direndam dalam aquadest selama 1 menit, direndam dalam HarrisHematoksilin selama 15 menit, direndam dalam aquadest selama 1 menit dan 15 menit, setelah itu direndam dalam eosin selama 2 menit yang dilanjutkan dengan direndam dalam alkohol $96 \%$ I selama 3 menit, alkohol 96\% II selama 3 menit, dan alkohol absolut III dan IV masing- masing selama 3 menit kemudian preparat dibilas dengan xylol I dan II masing-masing selama 5 menit. Lalu proses yang terakhir adalah menggunakan kanada balsam berisi entellan sebagai perekat (mounting) dan didiamkan hingga kering.

\section{Analisis Data}

Data berupa struktur histologi dianalisis secara deskriptif kualitatif, sedangkan data morfometri disajikan dalam bentuk rataan \pm simpangan baku (SB), kemudian dianalisis menggunakan Uji $\mathrm{T}$.

\section{HASIL DAN PEMBAHASAN}

\section{Hasil}

Hasil penelitian struktur histologi paruparu kambing PE jantan muda dan dewasa, betina muda dan dewasa disajikan pada Gambar 1, 2, 3, 4, dan 5. Struktur histologinya disusun oleh alveoli, kapsula, bronkus, dan bronkiolus. 


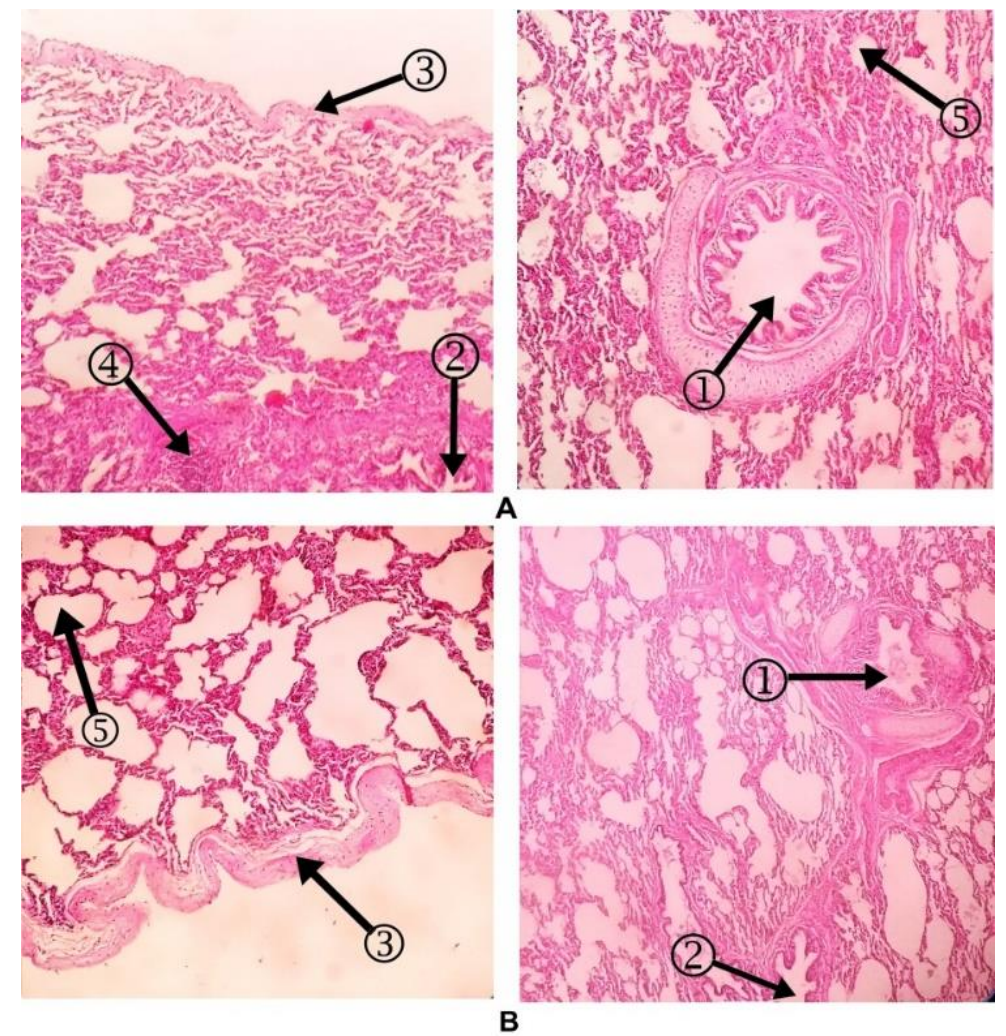

Gambar 1. Struktur histologi paru-paru kambing PE jantan muda (A) dan betina muda (B) (HE 50x) Ket:1. Bronkus, 2. Bronkiolus, 3. Kapsula, 4. Nodulus Limpatikus, 5. Alveoli
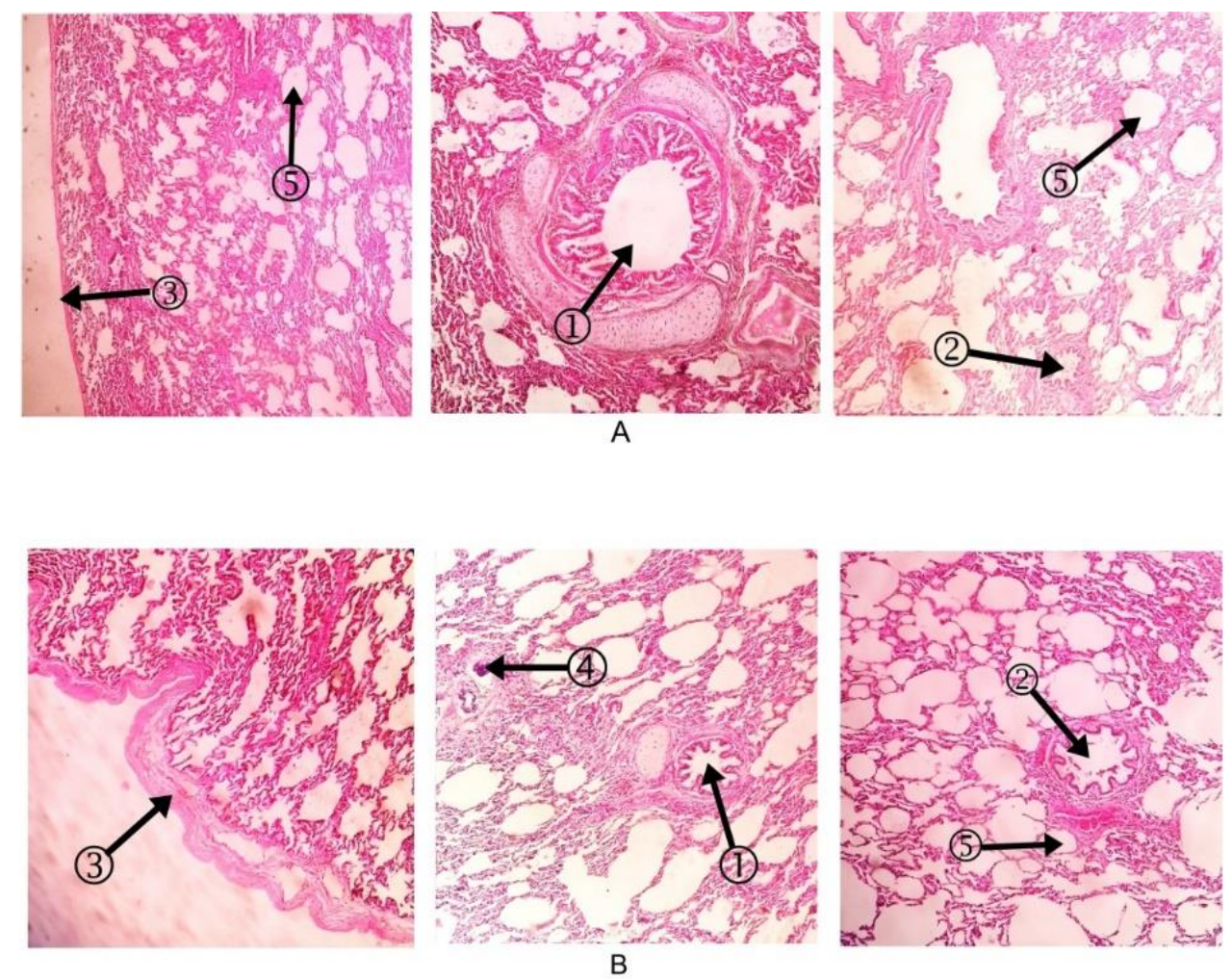

Gambar 2. Struktur histologi paru-paru kambing PE jantan dewasa (A) dan betina dewasa (B) (HE 50x) Ket: 1. Bronkus, 2. Bronkiolus, 3. Kapsula, 4. Nodulus Limpatikus, 5. Alveoli 
Struktur histologi kapsula paru-paru kambing PE dilapisi oleh pleura viscera, mesothelium, lymphatic, machropage, alveoli, dan elastic band. Pleura visceral kambing PE betina muda lebih padat dibandingkan dengan betina dewasa (Gambar 2). Kapsula kambing PE betina muda disusun oleh lymphatic yang tebal, sedangkan pada betina dewasa perbedaan ini tidak ditemukan. Pada kambing PE jantan terdapat alveoli dengan struktur yang rapat, sedangkan pada betina struktur alveolinya lebih renggang dan batas antara satu dengan yang lain kurang jelas.
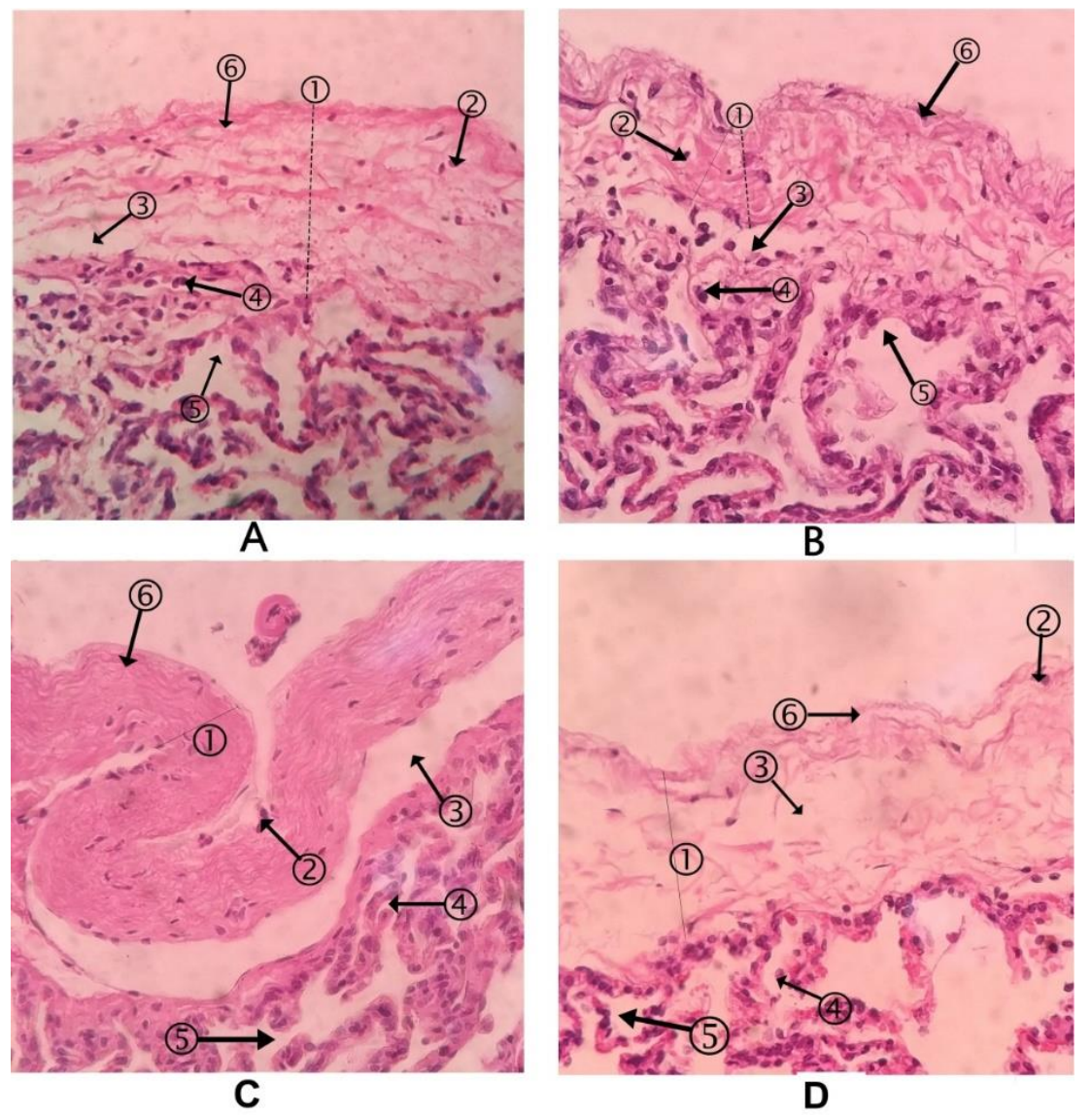

Gambar 3. Struktur histologi kapsula paru-paru kambing PE A) jantan muda, B) jantan dewasa, C) betina muda, D) betina dewasa. HE 400x. Ket: 1. Pleura Visceral, 2. Meshothelium, 3. Lymphatic, 4. Machropage, 5. Alveolus, 6. Elastic band

Struktur histologi bronkus tersusun dari tulang rawan hialin yang bentuknya tidak teratur, otot polos, arteri pulmonari dengan epitel pseudokomplek bersilia diatas lamina propria yang dibentuk oleh banyak serabut elastis, sedikit serabut kolagen dan retikuler. Pada kambing PE jantan ditemukan lebih banyak tulang rawan hialin dibandingkan betina. (Gambar 4). Tulang rawan hialin kambing $P E$ jantan yang berbentuk huruf c, dan melingkar diluar adventitia, sedangkan pada betina berbentuk bulat. Alveoli pada kambing PE jantan memiliki struktur yang rapat, sedangkan pada betina lebih renggang (Gambar 4). Pada kambing betina disusun oleh vili yang tinggi, sedangkan pada jantan villinya lebih pendek. Kambing PE muda memiliki vili yang tumpul, sedangkan pada kambing dewasa lebih runcing. 

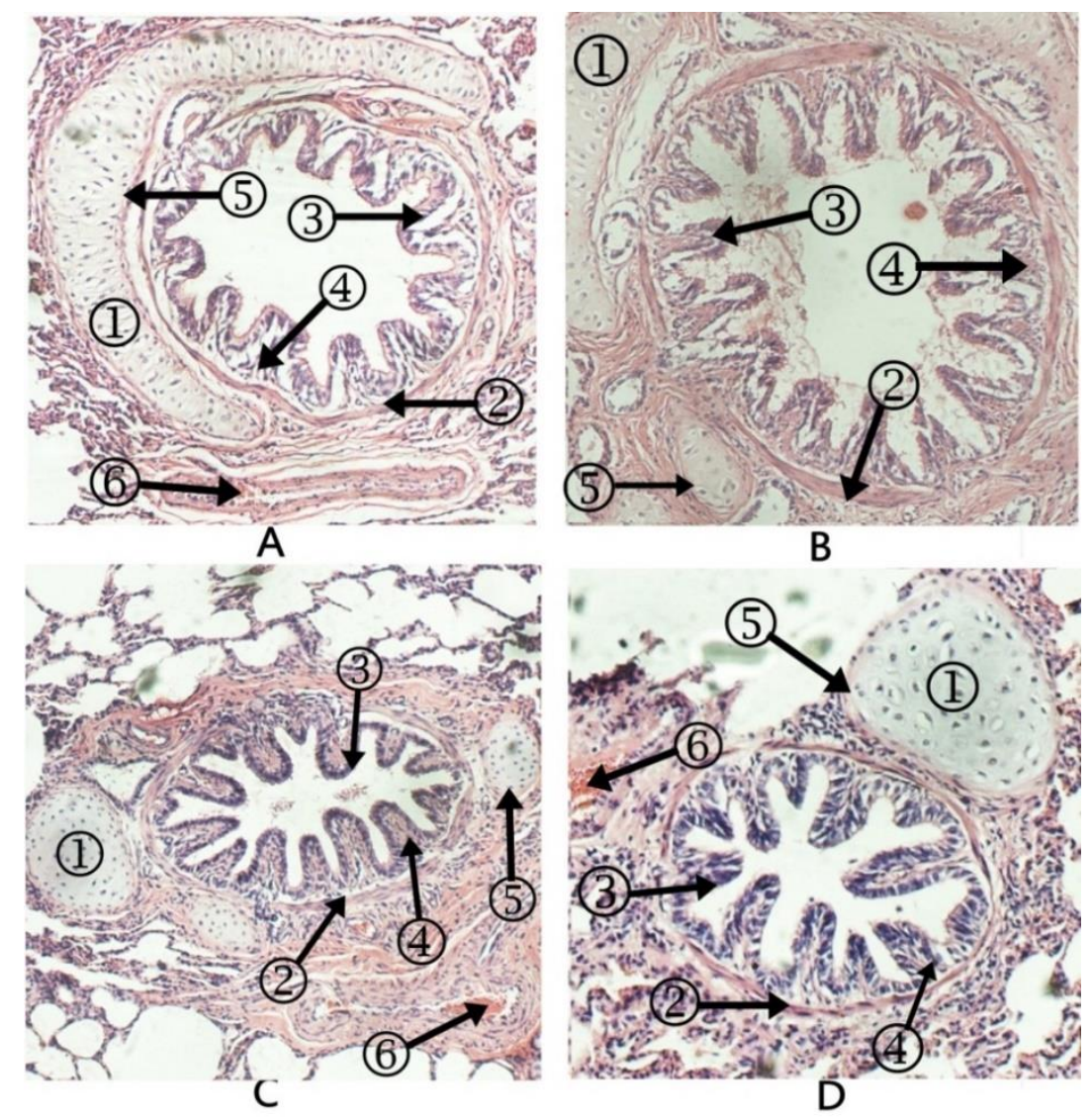

Gambar 4. Struktur histologi bronkus paru-paru kambing PE A) jantan muda, B) jantan dewasa, C) betina muda, D) betina dewasa. HE 100x Ket: 1. Tulang Rawan Hialin, 2. Otot Polos, 3. Epitel Pseudokomplek Bersilia, 4. Lamina Propria, 5. Perikandrium, 6. Arteri Pulmonari

Struktur histologi bronkiolus paru-paru kambing PE disusun oleh lamina propria yang elastis dan tipis, dikelilingi pita-pita otot polos yang terpilin longgar, lumennya dilapisi epitel kolumner simplek bersilia, pada bronkiolus tidak ditemukan tulang rawan hialin seperti pada bronkus. Otot polos bronkiolus kambing PE betina batasbatasnya kurang jelas dan terputus-putus
(Gambar 5. C dan D), sedangkan pada jantan lebih jelas dan membentuk lingkaran (Gambar 5. A dan B).

\section{Struktur Histomorfometri Paru-Paru Kambing PE}

Hasil pengukuran histomorfometri paru-paru kambing PE disajikan pada Tabel 1 .

Tabel 1. Hasil Pengukuran Histomorfometri Paru-Paru Kambing PE (rataan \pm sd)

\begin{tabular}{lccc}
\hline $\begin{array}{c}\text { Organ } \\
(\mu \mathrm{m})\end{array}$ & $\begin{array}{c}\text { Jenis } \\
\text { Kelamin }\end{array}$ & Muda & Dewasa \\
\hline \multirow{2}{*}{ Kapsula } & Jantan & $34,7 \pm 0,5^{\text {aa }}$ & $26,6 \pm 0,9^{\text {aa }}$ \\
& Betina & $25,3 \pm 0,8^{\text {aa }}$ & $16,3 \pm 0,6^{\text {aa }}$ \\
\multirow{2}{*}{ Bronkus } & Jantan & $91633,6 \pm 711,5^{\text {xx }}$ & $973786,8 \pm 6214,7^{\text {xy }}$ \\
& Betina & $74155,05 \pm 1639,9^{\mathrm{yx}}$ & $75341,6 \pm 946,2^{\mathrm{yy}}$ \\
\multirow{2}{*}{ Bronkiolus } & Jantan & $14623,6 \pm 359,6^{\mathrm{zz}}$ & $13165,5 \pm 630,5^{\mathrm{zz}}$ \\
& Betina & $15491,7 \pm 732,4^{\mathrm{zz}}$ & $10611,9 \pm 322,3^{\mathrm{zq}}$ \\
\hline
\end{tabular}

Keterangan: Huruf pertama yang berbeda pada satu kolom menunjukkan berbeda nyata $(\mathrm{P}<0,05)$, sedangkan huruf yang sama pada satu kolom menunjukkan tidak berbeda nyata $(\mathrm{P}>0,05)$. Huruf kedua yang berbeda pada satu baris menunjukkan berbeda nyata $(\mathrm{P}<0,05)$, sedangkan huruf yang sama pada satu baris menunjukkan tidak berbeda nyata $(\mathrm{P}>0,05)$. 

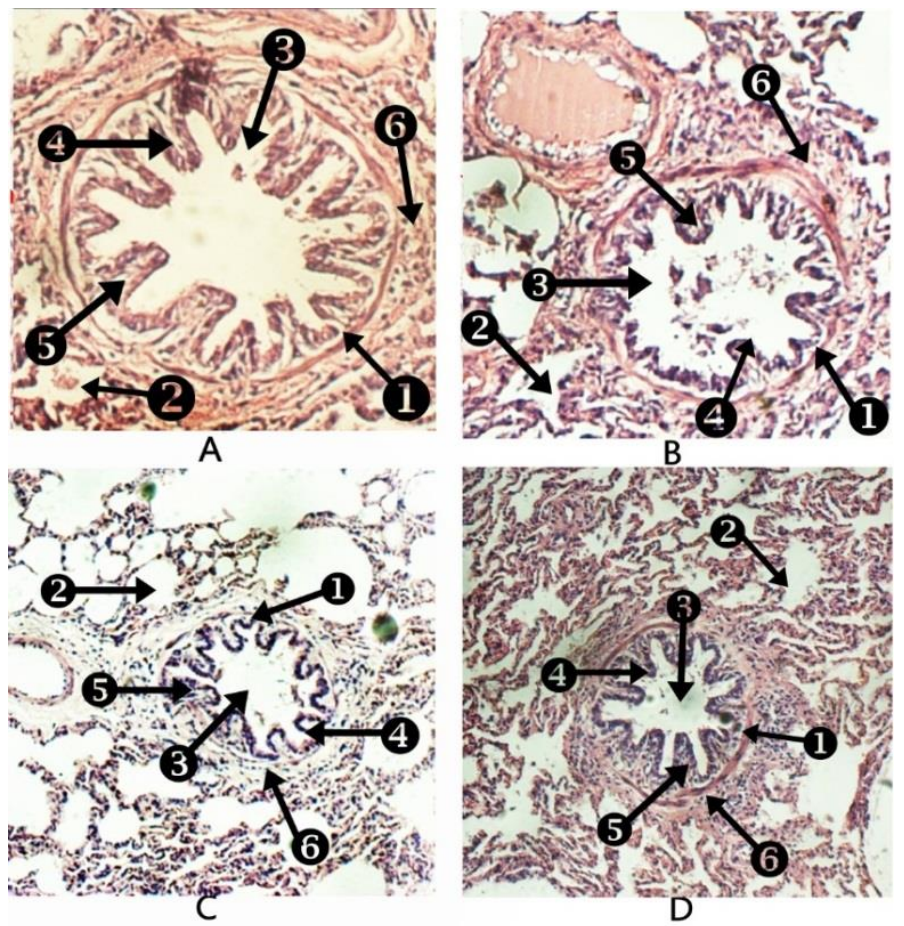

Gambar 5. Struktur histologi bronkiolus paru-paru kambing PE A) jantan muda, B) jantan dewasa, C) betina muda, D) betina dewasa. HE 100x Ket: 1. Otot polos, 2. Alveolus, 3. Bronkiolus, 4. Epitel Kolumner Simplek Bersilia, 5. Lamina Propria, 6. Adventitia, 7. Arteri Pulmonari

Tidak ada perbedaan ketebalan kapsula paru-paru kambing PE, tapi contour bronkus dan bronkiolus terdapat perbedaan $(\mathrm{P}<0,05)$. Bronkus kambing $\mathrm{PE}$ jantan dewasa memiliki contour paling luas $973786,8 \pm 6214,7$, sedangkan contour kambing betina muda paling sempit $74155,05 \pm 1639,9$.

Contour bronkus paru - paru kambing PE jantan muda lebih luas dibandingkan betina muda $(\mathrm{P}<0,05)$, contour bronkus pada kambing PE jantan dewasa lebih luas dibandingkan betina dewasa $(\mathrm{P}<0,05)$. Contour bronkiolus paru - paru kambing PE betina muda lebih luas dibandingkan jantan muda $(\mathrm{P}<0,05)$, sedangkan pada jantan dewasa lebih luas dibandingkan betina muda $(\mathrm{P}<0,05)$.

\section{Pembahasan}

Struktur histologi paru-paru kambing PE tersusun atas kapsula, bronkus, dan bronkiolus. Contour bronkus dan bronkiolus serta ketebalan kapsula ini memiliki ukuran yang berbeda baik dari sudut pandang jenis kelamin dan umur.

\section{Kapsula}

Kapsula paru-paru merupakan membrana serosa yang disebut dengan pleura visceral, ketebalannya pada semua kambing PE sama (Tabel 1). Kapsula merupakan pembungkus paru-paru yang terdiri atas lapisan tipis jaringan kolagen yang kaya fibroblast dan makrofag, ditemukan pula serabut elastis. Kapsula memiliki banyak serabut otot polos (Eroschenko, 2008).

Pleura visceral pada kambing PE jantan strukturnya lebih padat dibandingkan dengan kambing betina (Gambar 3), hal ini disebabkan ukuran anatomi paru hewan jantan lebih besar dibandingkan betina (Warganegara, 2015). Bacha (2012) berpendapat bahwa kapsula hewan karnivora relatif tipis, sedangkan kapsula mamalia domestik kecuali karnivora relatif tebal. Eroschenco (2008) juga berpendapat bahwa kapsula pada sapi tertebal dan pada karnivora paling tipis.

Pada kambing PE betina muda ditemukan lympathic yang tebal, 
sedangkan pada betina dewasa perbedaan ini tidak ditemukan. Hal tersebut dikarenakan seiring dengan pertambahan umur, kapasitas paru-paru akan menurun. Seperti dijelaskan pada penelitian yang dilakukan oleh (Kalita, 2014) dimana umur hewan berpengaruh terhadap struktur histologi kapsula. Pada kambing PE jantan terdapat alveoli dengan struktur yang rapat, sedangkan pada betina struktur alveolinya lebih renggang dan batas antara satu dengan yang lain kurang jelas, hal ini dikarenakan terjadi penurunan elastisitas alveoli, dimana pada hewan jantan ditemukan lebih tinggi 20-25\% dari pada betina (Warganegara, 2015).

Di bawah epithelium ditemukan jalajala serabut elastis yang memisahkan serosa dengan sub serosa. Sub serosa terdiri atas serabut kolagen, jaringan kolagen melanjutkan diri ke lobulus paru-paru, nodulus lympatikus ditemukan pada sub serosa (Eroschenko,2008). Ketebalan yang berbeda-beda yang ditemukan disebabkan faktor umur, jenis kelamin, dan spesies seperti pada kuda. Pada kuda, septa yang tidak lengkap meluas ke dalam dari pleura visceral, sedangkan pleura visceral pada babi dan ruminansia septanya lengkap (Bacha, 2012).

\section{Bronkus}

Bronkus kambing PE disusun oleh tulang rawan hialin, otot polos, arteri pulmonari, lamina propria, dan epitel pseudokomplek basilia (Gambar 4). Bronkus memiliki susunan struktural mukosa yang mirip dengan trakea kecuali susunan tulang rawan dan otot polosnya (Mescher, 2016). Saat memasuki paru-paru bronkus primer membelah dan menyebabkan bronkus yang lebih kecil atau intrapulmoner. Bronkus intrapulmonar dikelilingi oleh epitel pseudokomplek bersilia serta lamina propria jaringan ikat halus dengan serat elastis dan beberapa limfosit. Ditemukan lapisan tipis otot polos mengelilingi lamina propria dan memisahkannya dari submukosa, submukosa mengandung banyak kelenjar bronkus seromus. Saluran ekskretoris dari kelenjar bronkus melewati lamina propria untuk membuka ke lumen bronkiolus (Eroschenko, 2008).

Contour bronkus paru-paru kambing PE jantan muda lebih luas dibandingkan dengan kambing $\mathrm{PE}$ betina muda $(\mathrm{P}<0,05)$ dan pada kambing PE jantan dewasa lebih luas dibandingkan dengan kambing $\mathrm{PE}$ betina dewasa $(\mathrm{P}<0,05)$, hal ini dikarenakan ukuran anatomi paru hewan jantan lebih besar dibandingkan betina (Warganegara, 2015). Contour bronkus kambing PE jantan dewasa ditemukan paling luas $(\mathrm{P}<0,05)$ dibandingkan dengan jantan muda, betina muda, maupun betina dewasa. Hal ini diakibatkan perbedaan jenis kelamin dan umur dari hewan tersebut.

Pada lapisan mukosa bronkus ditemukan sel epitel pseudokomplek bersilia dengan lamina propria yang tipis. Mukosa bronkus memiliki beberapa lipatan, lipatan meningkat seiring penurunan diameter bronkus (Bacha, 2012). Dibawah mukosa terdapat otot polos yang tidak membentuk cincin, tetapi membentuk berkas yang terputus-putus dan makin kecil maka ruang makin lebar (Sadi, 2005). Diantara otot polos banyak ditemukan serabut elastis, jala - jala vasa yang padat banyak menembus jaringan fibroelastis (Eroschenko, 2008). Pada kambing betina disusun oleh vili yang tinggi, sedangkan pada jantan vilinya lebih pendek. Kambing PE muda memiliki vili yang tumpul, sedangkan pada kambing dewasa lebih runcing. hal ini sesuai dengan penelitian yang dilakukan oleh Kalita (2014) pada babi lokal mizo (zo vawk).

Bronkus primer ekstrapulmoner memiliki tulang rawan berbentuk huruf c, tulang rawan berbentuk huruf c umumnya ditemukan pada trakea (Mescher, 2016), hal ini terjadi karena bentuk dan ukuran dari tulang rawan hialin pada bronkus dipengaruhi oleh lokasi. Bentuk dan ukuran tulang rawan bronkus pada kambing PE ditemukan berbeda-beda, pada kambing PE jantan dewasa bentuknya seperti huruf $\mathrm{c}$, 
sedangkan pada betina berbentuk bulat (Gambar 4). Perbedaan ini membuktikan bentuk tulang rawan berkaitan dengan jenis kelamin dan umur.

Didalam lamina propria bronkus ditemukan otot polos yang tipis tersusun menyilang (Mescher, 2016), dan lebih jelas terlihat didekat bagian respirasi. Lamina propria ditemukan lebih tebal, mengandung serat elastis, kelenjar serosa dan mukosa, limfosit yang berfungsi sebagai pertahanan tubuh. Lapisan terluar berupa jaringan ikat padat yang banyak serabut elastis menyelubungi lempeng-lempeng tulang rawan (Kalita, 2014). Alveoli pada kambing PE jantan memiliki struktur yang rapat, sedangkan pada betina lebih renggang (Gambar 4), Hal tersebut disebabkan kambing PE jantan memiliki kapasitas paru - paru lebih besar dibandingkan betina, frekuensi pernapasan pada hewan jantan lebih cepat dari pada betina karena hewan jantan membutuhkan lebih banyak energi, sehingga menyebabkan kerapatan alveoli pada kambing PE jantan lebih rapat dari betina.

\section{Bronkiolus}

Struktur histologi bronkiolus terdiri atas mukosa, submukosa, adventitia, dan lamina propria (Gambar 5), bronkiolus tidak ditemukan tulang rawan maupun kelenjar dalam mukosanya, tetapi rongganya masih mempunyai silia dan lumennya dilapisi epitel kolumner simplek bersilia (Bacha, 2012).

Bronkiolus kambing PE betina tersusun oleh otot polos tipis dan kurang jelas batas - batasnya, sedangkan pada kambing PE jantan lebih jelas membentuk lingkaran (Gambar 5), hal ini dikarenakan jenis kelamin berpengaruh terhadap kapasitas paru - paru, kapasitas paru - paru hewan betina lebih kecil 20-25\% dari pada hewan jantan, sehingga kemungkinan aliran udara lebih lancar pada hewan jantan. Kelancaran aliran udara dapat mempengaruhi ketebalan otot polos pada bronkiolus, hal ini disebabkan otot polos bekerja lebih keras untuk menahan tekanan udara dalam bronkiolus akibat kurang lancarnya aliran udara pernafasan.

Alveoli bronkiolus muncul sebagai evaginasi kecil, setiap bronkiolus terbagi menjadi beberapa duktus alveolar, dinding saluran alveolar dilapisi oleh alveoli yang langsung terhubung ke saluran alveolar (Eroschenko, 2008). Pada lamina propria ditemukan jaringan ikat dan otot polos yang terpilin longgar, lapisan adventitia juga terdiri dari jaringan ikat elastis. Contour bronkiolus betina muda paling luas dibandingkan betina dewasa, jantan muda, dan jantan dewasa (Tabel 1), hal ini terkait dengan lapisan bronkus yang lebih tipis.

\section{SIMPULAN DAN SARAN}

\section{Simpulan}

Kambing peranakan etawah (PE) betina memiliki bronkus yang tersusun dari tulang rawan hialin berbentuk bulat, alveolinya renggang serta villi yang tinggi, pada kambing muda tersusun dari villi yang tumpul. Kambing dewasa villinya runcing, bronkiolus kambing PE betina tersusun dari otot polos dengan. Bronkus kambing PE jantan tersusun dari tulang rawan hialin berbentuk huruf $\mathrm{C}$, memiliki alveoli yang rapat serta villi yang pendek. Bronkiolus kambing PE jantan tersusun dari otot polos dengan batas yang jelas dan membentuk lingkaran.

\section{Saran}

Perlu dilakukan penelitian tentang gambaran histologi dan histomorfometri paru-paru kambing peranakan etawah dan dibandingkan dengan spesies hewan yang lain

\section{UCAPAN TERIMA KASIH}

Penulis mengucapkan terimakasih kepada Kepala Balai Besar Veteriner beserta staf dan tenaga laboran atas ijin dan pelaksanaan penelitian ini.

\section{DAFTAR PUSTAKA}

Bacha WJJ, Bacha LM. 2012. Color atlas of veterinary histology. $3^{\text {rd }} \mathrm{Ed}$. Wilwy and Blackwell. 
Dhewiyanty V, Setyawati TR, Yanti AH. 2015. Prevalensi dan Intensitas Larva Infektif Nematoda Gastrointestinal Strongylida dan Rhabditida pada Kultur Feses kambing (Capra sp.) di Tempat Pemotongan Hewan Kambing Pontianak.

Edey IN. 1983. Tropical Sheep and Goat Production. Australia University International Development Program Canberra.

Eroschenko VP. 2008. Difiore's Atlas of Histology with Functional Correlations. $11^{\text {th }}$ Ed.

Federer PG. 1997. Experimental Design Theory and Application. Third Edition. Oxford and IBH Publishing Co. New Delhi Bombay Calcuta

Irmawati D, Fuah AM, Setyono DJ. 2013. Sistem Produksi dan Kelayakan Usaha Peternakan Kambing Peranakan Etawah. J. Ilmu Prod. Teknologi Peternakan. 01(2):104-109.

Kalita A. 2014. Histomorphological Study of the Respiratory System of Mizo Local Pig (zo vawk). Department of Veterinary Anatomy and Histology,
College of Veterinary Sciences and A.H. Central Agricultural University, Selesih, Aizawl, Mizoram, India.

Mescher AL. 2016. Junqueira's Basic Histology, Text and Atlas. $14^{\text {th }}$ Ed. Vet Books.

Prabowo A. 2010. Petunjuk Teknis Budidaya Ternak Kambing. Balai Pengkajian Teknologi Pertanian Sumatra selatan, Palembang.

Sadi SEJA. 2005. Topographical and histological study of the lung in the sheep and goats. Colle. of Vet. Med. Unive. of Mosul.

Suparman, Hafid H, Baa LO. 2016. Kajian Pertumbuhan Dan Produksi Kambing Peranakan Ettawa Jantan Yang Diberikan Pakan Berbeda. Fakultas Peternakan UHO

Suwiti NK, Suastika IP, Swacita IBN, Besung INK. 2015. Studi Histologi dan Histomorfometri Daging Sapi Bali dan Wagyu. J. Vet. 16(3): 432-438.

Warganegara RK. 2015. The Comparation Of Lung Vital Capacity in Various Sport Athlete. Faculty of Medicine, Lampung University. 